\title{
ANALISIS SIKAP KONSUMEN TERHADAP PENGGUNAANPRODUK DETERJEN MAKE CLEAN DI KALANGAN LAUNDRY YOGYAKARTA DENGAN METODE STATISTIK UJI BEDA DUA MEAN
}

\author{
Jono \\ Jurusan Teknik Industri \\ Universitas Widya Mataram Yogyakarta \\ Dalem mangkubumen KT III/ 237 Yogyakarta \\ Yonuwm@yahoo.co.id
}

\begin{abstract}
Abstrak
Penelitian ini bertujuan untuk mengetahui bagaimana sikap pengusaha laundry pria dan wanita terhadap deterjen merek Make Clean di kalangan laundry Yogyakarta terhadapt atribut harga, merk, kemasan, promosi dan performansi. Kemudian apakah ada perbedaan sikap antara pengusaha laundry pria dan wanita, dan dari kelima atribut tersebut, atribut manakah yang paling mempengaruhi pengusaha laundry dalam melakukan pembelian produk Make Clean.Data penelitian diambil dengan menggunakan kuisioner, wawancara dan observasi kepada 100 pengusaha laundry sebagai sampel. Sampel diambil dengan menggunakan teknik ramdom sampling. Data yang diperoleh diuji dengan uji validitas dan uji reliabilitas, dianalisis dengan analisis kualitatif dan analisis kuantitatif.Hasil uji analisis aritmatik mean diketahui bahwa sikap pengusaha laundry terhadap atribut-atribut deterjen merek Make Clean untuk pengusaha pria mempunyai penilaian negatif, sedangkan wanita mempunyai sikap penilaian yang positif. Hasil uji hipotesis tentang sikap pengusaha pria dan wanita secara keseluruhan dengan menggunakan uji beda 2 mean dapat disimpulkan bahwa -1,96 < $Z_{\text {hitung }}<1,96(-2,883<-1,96)$. Artinya bahwa Analisis sikap pengusaha pria dan wanita secara keseluruhan terhadap atribut produk deterjen merek Make Clean di kalangan laundry kiloan di Yogyakarta ada perbedaan yang signifikan.
\end{abstract}

Kata kunci : Analisis, sikap konsumen, aritmetik mean, uji beda 2 mean

\section{PENDAhuluan}

Di Yogyakarta telah banyak bermunculan usaha baru, salah satunya adalah usaha bisnis laundry. Saat ini bisnis laundry tumbuh dan berkembang pesat ibarat jamur di musim hujan. Melihat pertumbuhan bisnis tersebut tentunya akan dilirik oleh pengusaha yang menyediakan bahan kebutuhan pokok untuk laundry yaitu produsen deterjen.

Menyikapi hal tersebut, salah satu yang menjadi kebutuhan pokok untuk bisnis laundry yaitu kebutuhan akan deterjen. Deterjan yang diambil dalam penelitian ini adalah deterjen merk Make Clean yang diproduksi dan dipasarkan oleh PT XYZ Yogyakarta. Perusahaan tersebut telah memproduksi berbagai kebutuhan chemical laundry seperti deterjen, pelembut, penghilang noda dan pewangi. Melihat perkembangan tingkat penggunaan dan kompetisi antar produk deterjen, maka keinginan pengusaha laundry terhadap produk deterjen bermacam-macam. Karena pengusaha laundry terdiri dari pria dan wanita maka ingin dibandingkan bagaimana sikap antara pengusaha laundry pria dan wanita terhadap produk deterjen yang ditawarkan.

Untuk itu perusahaan seharusnya mampu mempublikasikan produknya kepada konsumen supaya dapat mengatasi persaingan dan mendapat tempat untuk merebut konsumen sebanyak mungkin.Selain itu perusahaan juga harus mampu menciptakan dan menampilkan citra baik produknya agar dapat mencapai kepuasan konsumen. Berdasar pernyataan diatas diambil atribut harga, merk, kemasan, promosi dan performansi untuk melihat sikap pengusaha laundry pria dan wanita.

Suatu perusahaan dikatakan berhasil apabila perusahaan tersebut mampu memasarkan hasil produksi dengan baik.Keberhasilan ini tercermin dari luar pasar yang dapat dikuasai oleh perusahaan tersebut.Kegiatan operasional perusahaan dalam lingkungan yang terus menerus berkembang adalah konsekuensi sosial dari perusahaan tersebut.Bagi perusahaan 
perubahan lingkungan merupakan tantangan baru yang memerlukan tanggapan agar diperoleh kesempatan untuk mengembangkan pasar atau usahanya.

Untuk mengetahui keinginan konsumen, perlu diketahui dengan baik perilaku konsumen.Salah satu faktor yang mempengaruhi perilaku konsumen adalah persepsi, sedangkan persepsi itu sendiri merupakan daya penerima individu dalam menginterprestasikan aspek lingkungan" (Simamora,2005).Dari penerimaan individu itu terjadi tanggapan dan berlanjut dengan terbentuknya suatu sikap.Karena itu menjadi sangat penting untuk mengetahui persepsi konsumen terhadap produk yang ditawarkan perusahaan.

\section{Tujuan Penelitian}

1. Untuk mengetahui bagaimana sikap pengusaha laundry pria dan wanita terhadap produk deterjen merek Make Clean di kalangan Laundry Yogyakarta berdasarkan atributatribut produk yaitu harga, merek, kemasan, promosi dan performansi.

2. Untuk mengetahui apakah ada perbedaan sikap pengusaha laundry pria dan wanita terhadap produk deterjen merek Make Clean di kalangan Laundry Yogyakarta berdasarkan atribut-atribut produk yaitu harga, merek, kemasan, promosi dan performansi.

3. Untuk mengetahui atribut manakah yang paling mempengaruhi pengusaha laundry dalam melakukan pembelian produk deterjen merek Make Clean di kalangan Laundry Yogyakarta berdasarkan atribut-atribut produk yaitu harga, merek, kemasan, promosi dan performansi.

\section{TINJAUAN PUSTAKA}

\section{A. Pengertian Pemasaran}

Menurut Staton dalam Basu Swastha (2000: 5) "Pemasaran adalah suatu sistem dalam pemasaran dari kegiatan bisnis yang ditujukan untuk merencanakan, menentukan harga dan mendistribusikan barang dan jasa yang memuaskan kebutuhan baik kepada pembeli yang ada maupun pembeli potensial".

Menurut Kotler dan Keller (2007) "Manajemen Pemasaran adalah analisis, perencanaan, implementasi dan pengendalian dari program-program yang dirancang untuk menciptakan, membangun dan memelihara pertukaran yang menguntungkan dengan pembeli sasaran untuk mencapai tujuan perusahaan".

\section{B. Konsep Pemasaran}

Pemasaran merupakan hal penting bagi kesuksesan dan keberhasilan suatu perusahaan. Kotler dan Keller (2007) mengemukakan bahwa terdapat 5 falsafah yang dapat dijadikan sebagai pedoman usaha pemasaran adalah sebagai berikut :

1. Konsep produksi yaitu falsafah yang menyatakan bahwa konsumen akan menyukai produk yang mudah diperoleh dan sangat terjangkau, sehingga manajemen harus berfokus pada perbaikan efisiensi produksi dan distribusi.

2. Konsep produk yaitu konsumen akan menyukai produk yang menawarkan mutu terbaik, kinerja terbaik dan sifat terbaik dan bahwa organisasi mencurahkan tenaga untuk melakukan perbaikan produk terus-menerus.

3. Konsep penjualan yaitu konsumen tidak akan membeli cukup banyak produk perusahaan kecuali jika perusahaan tersebut melakukan usaha penjualan dan promosi dalam skala besar.

4. Konsep pemasaran yaitu untuk mencapai tujuan organisasi tergantung pada penentuan kebutuhan dan keinginan pasar sasaran (target market) dan memuaskan pelanggan secara lebih efektif daripada yang dilakukan pesaing.

5. Konsep pemasaran berwawasan sosial yaitu organisasi harus menentukan kebutuhan, keinginan dan minat pasar sasaran dan memberikan yang diharapkan secara lebih efektif dan efisien daripada pesaing, dengan suatu cara yang dapat menjaga dan meningkatkan kesejahteraan pelanggan dan masyarakat. 
Menurut Basu Swastha dan T. Hani Handoko (1984) "Konsep Pemasaran adalah falsafah bisnis yang menyatakan bahwa pemuasan kebutuhan konsumen merupakan syarat ekonomi dan sosial bagi kelangsungan hidup perusahaan".

\section{Manajemen Pemasaran}

Definisi manajemen pemasaran adalahpenganalisaan, pelaksanaan dan pengawasan program-program yang bertujuan menimbulkan pertukaran dengan pasar yang dituju dengan maksud untuk mencapai tujuan perusahaan (Siswanto Sutojo, 2009).

Jadi manajemen pemasaran dirumuskan sebagai suatu proses manajemen yang meliputi penganalisaan dan pengawasan kegiatan pemasaran perusahaan. Kegiatan ini bertujuan menimbulkan pertukaran yang diinginkan, baik menyangkut barang maupun jasa atau benda-benda lainnya yang dapat memenuhi kebutuhan psikologi, sosial dan budaya.

\section{Pengertian Sikap Konsumen}

Sikap konsumen merupakan suatu kecenderungan yang dipelajari untuk bereaksi terhadap penawaran produk dalam masalah yang baik ataupun kurang baik secara keseluruhan. Dalam hal ini sikap konsumen pria dan wanita terhadap deterjen merek Make Cleanadalah:

1. Pria

Pria cenderung mempunyai sikap ingin cepat selesai dalam mencuci pakaian,jadi komposisi dalam mencuci pakaian untuk pria lebih terburu-buru dari wanita, atau mempunyai sikap yang praktis terhadap detergen bila dibandingkan dengan wanita.

2. Wanita

Wanita cenderung mempunyai sikap lebih teliti dalam mencuci pakaian, jadi komposisi dalam mencuci pakaian untuk wanita lebih berhati-hati dari pria, atau mempunyai sikap yang selektif terhadap deterjen bila dibandingkan dengan pria.

Sikap konsumen adalah tanggapan dari konsumen terhadap atribut produk seperti harga, merek, kemasan, promosi dan performansi yang terdapat pada deterjen merek Make Clean. Dan atribut-atribut yang melekat pada produk tersebut adalah:

1. Harga

Adalah nilai pertukaran atas manfaat produk bagi konsumen maupun bagi produsen yang umumnya dinyatakan dalam satuan rupiah.Harga merupakan faktor penting dalam menarik pelanggan atau konsumen.Sedangkan nilai adalah ungkapan secara kuantitatif tentang kekuatan produk agar menarik minat konsumen untuk melakukan penukaran yang sebanding. Swastha dan Handoko (1984) mengemukakan bahwa "Harga adalah jumlah uang (ditambah beberapa barang kalau mungkin) yang dibutuhkan untuk mendapatkan sejumlah kombinasi dari barang serta pelayanannya."

2. Merek

Adalah nama, istilah, tanda, simbol atau lambang, desain, warna, atau kombinasi atribut-atribut produk lainnya yang diharapkan dapat memberikan identitas dan deferensiasi terhadap produk pesaing.

3. Kemasan

Adalah proses berkaitan dengan perancangan dan pembuatan wadah (Container) atau pembungkus (Wrapper) untuk suatu produk. Kemasan atau pengemasan mencakup semua kegiatan merancang dan memproduksi wadah atau pembungkus untuk suatu produk.

4. Promosi

Adalah usaha perusahaan untuk memberitahu, membujuk atau mengingatkan konsumen tentang perusahaan, produknya atau idenya agar tujuan perusahaan dapat tercapai. 


\section{Performansi}

Adalah kinerja dan manfaat dari produk dan jasa secara aktual dilihat dari dimensi

kepentingan konsumen.

\section{E. Perilaku Konsumen}

Tujuan kegiatan pemasaran yaitu mempengaruhi pembeli untuk membeli barang dan jasa perusahaan. Untuk itu perusahaan harus memiliki dinamika pemasaran yang selaras dengan keinginan dan kebutuhan manusia, dengan cara mengetahui perikau konsumen yang melandasi terjadinya pembelian. Perilaku konsumen dapat didefinisikan sebagai berikut: "Kegiatan-kegiatan individu yang secara langsung mendapatkan dan mempergunakan barang dan jasa, termasuk dalam proses pengambilan keputusan pada persiapan dan penentuan kegiatan-kegiatan tersebut". (Swastha dan Handoko, 1984)

\section{F. Sikap}

\section{Definisi sikap:}

"Sikap adalah menggambarkan penilaian kognitif yang baik maupun yang tidak baik, perasaan emosional dan kecenderungan berbuat yang bertahan selama waktu tertentu terhadap beberapa obyek atau gagasan" (Kotler dan Keller, 2007).

Sedangkan definisi sikap dalam pemasaran yang lain adalah:

"Suatu kecenderungan yang dipelajari untuk bereaksi terhadap penawaran produk dalam masalah yang baik ataupun kurang baik secara keseluruhan" (Swastha dan Handoko, 1984).

Sikap konsumen bisa merupakan sikap yang positif maupun yang negatif terhadap produk tertentu dengan mempelajari keadaan jiwa, keadaan pikiran dan sikap seseorang diharapkan dapat menentukan perilaku seseorang.

Sikap menentukan tingkah laku dalam hubungan yang relevan. Dengan mempelajari sikap konsumen terhadap produk yang dihasilkan perusahaan maka akan mengetahui respon yang diinginkan oleh konsumen.

\section{Komponen Sikap}

a. Komponen kognitif (Komponen keyakinan)

Yaitu merupakan pengetahuan, kepercayaan dan pikiran yang didasarkan pada informasi yang berhubungan dengan obyek.

b. Komponen perilaku (Komponen perasaan)

Yaitu melibatkan salah satu predisposisi (keadaan mudah terpengaruh untuk bertindak)

c. Komponen afektif (Perasaan)

Yaitu menunjukan pada dimensi emosional dari sikap yaitu emosi yang berhubungan dengan obyek atau fenomena secara umum. Komponen afektif merupakan hasil evaluasi terhadap pilihan-pilihan atribut dan karakteristik produk

\section{Ciri-ciri Sikap}

Sikap menentukan tingkah laku dalam hubungannya dengan perangsang yang relevan, atau kejadian. Adapun ciri-cirinya adalah sebagai berikut :

a. Sikap bukan bawaan manusia sejak lahir, melainkan terbentuk selama perkembangan akibat hubungan dengan obyek-obyek di lingkungan.

b. Sikap dapat berubah sebagai hasil interaksi antara seseorang dengan orang lain.

c. Sikap tidak berdiri sendiri melainkan mengadakan suatu hubungan dengan obyek.

d. Sikap bersangkutan dengan dimensi waktu yang berarti sikap hanya cocok untuk situasi waktu tertentu, yang belum tentu sesuai dengan waktu lain. 


\section{G. Uji Validitas Dan Reliabilitas}

\section{Uji Validitas}

Validitas berasal dari Bahasa Inggris yaitu validity yang berarti sejauh mana ketepatan dan kecermatan suatu instrumen. Jadi validitas berkaitan dengan permasalahan apakah instrumen yang dimaksudkan untuk mengukur sesuatu itu memang dapat mengukur secara tepat sesuatu yang diukur tersebut. Misalnya jika kita menggunakan kuisioner, uji validitas digunakan untuk mengukur sah atau valid tidaknya kuisioner yang diajukan peneliti. Suatu kuisioner dikatakan valid jika pertanyaan dalam kuisioner tersebut mampu mengungkapkan sesuatu yang diukur.

Adapun cara-cara untuk mempertimbangkan kadar validitas sebuah instrumen secara garis besar dibedakan menjadi dua yaitu analisis rasional dan analisis data empirik. Untuk validitas empirik ini diperlukan data-data statistik yang harus diuji dengan analisis statistik yang pada umumnya menggunakan korelasi baik korelasi pearson, Kendall dan spearman.

a. Korelasi Pearson $(r)$

Rumus yang digunakan untuk menghitung koefisien korelasi dengan menggunakan metode ini adalah:

$$
r=\frac{N \sum X Y-\left(\sum X\right)\left(\sum Y\right)}{\sqrt{\left(N \sum X^{2}-\left(\sum X\right)^{2}\right)\left(N \sum Y^{2}-\left(\sum Y\right)^{2}\right)}}
$$

Dimana :

$\mathrm{r}=$ koefisien korelasi Pearson

$X=$ variabel 1

$Y=$ variabel 2

$N=$ jumlah keseluruhan data

b. Korelasi Kendall $(\tau)$

Rumus yang digunakan untuk menghitung koefisien korelasi dengan menggunakan metode ini adalah:

$$
\tau=\frac{\mathrm{P}-\mathrm{Q}}{1 / 2 \mathrm{~N}(\mathrm{~N}-1)}
$$

Dimana:

$P=$ Jumlah angka peringkat yang lebih tinggi

$Q=$ Jumlah angka peringkat yang lebih rendah

$N=$ jumlah seluruh anggota

$\tau=$ koefisien korelasi Kendall

c. Korelasi Spearman $(\rho)$

Rumus yang digunakan untuk menghitung koefisien korelasi dengan menggunakan metode ini adalah:

$$
\rho=1-\frac{6 \sum D^{2}}{N\left(N^{2}-1\right)}
$$

Dimana:

$$
\begin{aligned}
& \rho=\text { koefisien korelasi Spearman } \\
& D=\text { perbedaan skor antara dua kelompok pasangan } \\
& N=\text { jumlah kelompok }
\end{aligned}
$$

\section{Uji Reliabilitas}

Reliabilitas juga berasal dari Bahasa Inggris yaitu reliability yang berari sejauh mana hasil suatu pengukuran dapat dipercaya. Hal ini menunjukkan pengertian bahwa suatu instrumen dikatakan reliabel jika dapat mengukur sesuatu yang diukur secara konsisten. Hasil pengukuran yang diperoleh untuk kelompok objek yang 
sama,akan relatif sama selama aspek dalam objek memang belum berubah. Pengujiannya dapat dilakukan baik secara internal maupun eksternal baik dengan menggunakan metode test-rest, equivalent, atau gabungan keduanya maupun dengan menggunakan metode internal konsistensi. Teknik pengujian reliabilitas yang sering digunakan antara lain:

a. Spearman-Brown (belah dua/split half)

Langkah-langkah uji reliabilitas dengan menggunakan metode ini adalah sebagai berikut:

- Analisis jawaban perobjek penelitian per butir

- Identifikasi jawaban benar dan salah subjek penelitian terhadap tiap butir pertanyaan nomor genap dan ganjil kemudian dijumlahkan

- Hasil penjumlahan skor benar nomor ganjil dan genap dikorelasikan hasilnya merupakan korelasi antar paruh soal.

- Berdasarkan koefisien korelasi yang diperoleh kemudian dilakukan penghitungan terhadap besarnya indeks reliabilitas secara keseluruhan instrumen penelitian dengan menggunakan rumus sebagai berikut:

$$
\mathrm{r}_{\mathrm{ns}}=\frac{2 \mathrm{r}_{\mathrm{gg}}}{1+\mathrm{r}_{\mathrm{gg}}}
$$

Dimana:

$\mathrm{r}_{\mathrm{ns}}=$ koefisien korelasi keseluruhan soal

$r_{g g}=$ koefisien korelasi separuh soal (nomor ganjil-genap)

b. Alfa Cronbach

Rumus yang digunakan untuk menghitung koefisien korelasi dengan menggunakan metode ini adalah:

$$
\mathrm{R}=\frac{\mathrm{k}}{\mathrm{k}-1}\left(1-\frac{\sum \sigma_{\mathrm{i}}{ }^{2}}{\sigma^{2}}\right)
$$

Dimana

$R=$ koefisien reliabilitas alfa cronbach

$k=$ jumlah butir pertanyaan

$\sigma_{i}^{2}=$ variansi butir-butir pertanyaan

$\sigma^{2}=$ variansi skor test

Sedangkan untuk rumus variansi butir pertanyaan ke- $n$ adalah sebagai berikut:

$$
\sigma_{i}^{2}=\frac{\sum \mathrm{X}_{\mathrm{i}}{ }^{2}-\frac{\left(\sum \mathrm{X}_{\mathrm{i}}\right)^{2}}{\mathrm{~N}}}{\mathrm{~N}}
$$

Dimana $\sum \mathrm{X}_{\mathrm{i}}=$ jumlah skor jawaban subjek untuk butir pertanyaan ke- $n$

\section{H. Uji Hipotesis Rata-rata}

Untuk memperoleh informasi mengenai suatu parameter atau lebih singkatnya untuk mengetahui parameter dari suatu populasi maka diperlukan pengambilan sampel. Dalam pengambilan sampel ini, diharapkan mampu menginterferensikan parameter yang tidak diketahui misalnya suatu populasi diketahui mempunyai distribusi normal, tetapi parameter rata-rata $\mu$ dan simpangan baku $\sigma$ tidak diketahui. Untuk itulah dalam statistik inferensia ada dua cara untuk mengetahui parameter suatu populasi yaitu dengan cara melakukan pendugaan parameter dan pengujian hipotesis.

Selisih rata-rata 2 Populasi

Misalkan 2 buah populasi suatu hasil penelitian atau pengamatan berdistribusi normal dengan rata-rata $\mu_{1}$ dan $\mu_{2}$ dengan standar deviasi $\sigma_{1}$ dan $\sigma_{2}$, akan diuji parameter rata- 
rata kedua populasi tersebut. Untuk keperluan ini maka diambil 2 sampel lalu dihitung rata-rata anggaplah sebagai $\overline{\mathrm{X}}_{1}$ dan $\overline{\mathrm{x}}_{2}$, standar deviasi kedua sampel tersebut adalah $\mathrm{S}_{1}$ dan $\mathrm{S}_{2}$.

Jika sampel yang diambil besar atau standar deviasi kedua populasi $\sigma_{1}$ dan $\sigma_{2}$ dan diketahui maka nilai statistik hitung $\mathrm{Z}$ yang digunakan dicari dengan menggunakan rumus di bawah ini.

$$
\mathrm{Z}=\frac{\left(\overline{\mathrm{x}}_{1}-\overline{\mathrm{x}}_{2}\right)}{\sqrt{\frac{\sigma_{1}^{2}}{\mathrm{n}_{1}}+\frac{\sigma_{2}^{2}}{\mathrm{n}_{2}}}}
$$

Sehingga interval konfidensi $(1-\alpha) \%$ untuk mean 2 populasi dinyatakan sebagai berikut:

$$
\left(\bar{x}_{1}-\bar{x}_{2}\right)-Z_{\frac{\alpha}{2}} \sqrt{\frac{\sigma_{1}^{2}}{n_{1}}+\frac{\sigma_{2}^{2}}{n_{2}}}<\left(\mu_{1}-\mu_{2}\right)<\left(\bar{x}_{1}-\bar{x}_{2}\right)+Z_{\frac{\alpha}{2}} \sqrt{\frac{\sigma_{1}^{2}}{n_{1}}+\frac{\sigma_{2}^{2}}{n_{2}}}
$$

Kemudian dilakukan pengujian hipotesis sebagai berikut:

Uji dua arah

Uji satu arah

$$
\begin{array}{ll}
\mathrm{H}_{0}: \mu_{1}=\mu_{2} & \mathrm{H}_{0}: \mu_{1}=\mu_{2} \\
\mathrm{H}_{1}: \mu_{1} \neq \mu_{2} & \mathrm{H}_{1}: \mu_{1}<\mu_{2}
\end{array} \quad \text { atau } \quad \begin{aligned}
& \mathrm{H}_{0}: \mu_{1}=\mu_{2} \\
& \mathrm{H}_{1}: \mu_{2}>\mu_{2}
\end{aligned}
$$

Daerah kritis Daerah kritis Daerah kritis

$$
Z<Z_{\frac{\alpha}{2}} \text { dan } Z>Z_{\left(1-\frac{\alpha}{2}\right)} \quad Z<Z_{a} \quad Z>Z_{(1-a)}
$$

Sedangkan untuk sampel kecil atau dengan kata lain standar deviasi $\sigma_{1}$ dano $_{2}$ sama tetapi tidak diketahui maka nilai statistik hitung $\mathrm{Z}$ di atas tidak digunakan dan digantikan dengan nilai $t$, yang dirumuskan sebagai berikut:

$$
\mathrm{t}=\frac{\left(\overline{\mathrm{x}}_{1}-\overline{\mathrm{x}}_{2}\right)}{\sqrt{\frac{\mathrm{S}_{1}^{2}}{\mathrm{n}_{1}}+\frac{\mathrm{S}_{2}^{2}}{\mathrm{n}_{2}}}}
$$

Sehingga interval konfidensi untuk mean 2 populasi dapat dinyatakan sebagai berikut:

$\left.\left(\bar{x}_{1}-\bar{x}_{2}\right)-t_{\left(\frac{\alpha}{2}, \text { df }\right.}\right) \sqrt{\frac{S_{1}^{2}}{n_{1}}+\frac{S_{2}^{2}}{n_{2}}}<\left(\mu_{1}-\mu_{2}\right)<\left(\bar{x}_{1}-\bar{x}_{2}\right)+t\left(\frac{\alpha}{2}\right.$, df $) \sqrt{\frac{S_{1}^{2}}{n_{1}}+\frac{S_{2}^{2}}{n_{2}}}$

Dengan $S_{1}$ dan $S_{2}$ adalah simpangan baku sampel, $d f$ adalah derajat kebebasan yang dapat dicari dengan menggunakan rumus $d f=\mathrm{n}_{1}+\mathrm{n}_{2}-2$ jika sampel yang diambil sama tetapi jika sampel yang diambil berbeda maka $d f$ dapat dicari dengan menggunakan rumus sebagai berikut:

$\mathrm{df}=\left(\frac{\mathrm{S}_{1}^{2}}{\mathrm{n}_{1}}+\frac{\mathrm{S}_{2}^{2}}{\mathrm{n}_{2}}\right):\left(\frac{\left(\mathrm{S}_{1}^{2} / \mathrm{n}_{1}\right)^{2}}{\mathrm{n}_{1}-1}+\frac{\left(\mathrm{S}_{2}^{2} / \mathrm{n}_{2}\right)^{2}}{\mathrm{n}_{2}-1}\right)$

Uji hipotesis yang digunakan adalah:

Uji dua arah

$\mathrm{H}_{0}: \mu_{1}=\mu_{2}$

$\mathrm{H}_{1}: \mu_{1} \neq \mu_{2}$

Daerah kritis

$\mathrm{t}<-\mathrm{t}_{\left(\frac{a}{2}, \text {,ff }\right.}$ dan $\mathrm{t}>\mathrm{t}_{\left(\frac{\mathrm{a}}{2}, \mathrm{df}\right)}$
Uji satu arah

$\mathrm{H}_{0}: \mu_{1}=\mu_{2}$

$\mathrm{H}_{1}: \mu_{1}<\mu_{2}$

Daerah kritis

$\mathrm{t}<-\mathrm{t}_{(\mathrm{a}, \mathrm{df})}$ atau

$\mathrm{H}_{0}: \mu_{1}=\mu_{2}$

$\mathrm{H}_{1}: \mu_{2}>\mu_{2}$

Daerah kritis

$t>t_{(a, d f)}$ 
Daerah kritis dalam uji hipotesis adalah batas-batas penolakan Hipotesis nol $\left(\mathrm{H}_{0}\right)$, atau nilai pembanding statistik hitung yang diperoleh dari tabel-tabel statistik yang digunakan.

\section{METODOLOGI PENELITIAN}

Dalam penelitian ini penulis menggunakan 2 (dua) metode yaitu metode analisis kualitatif dan analisis kuantitatif untuk mengetahui sikap konsumen terhadap penggunaan produk deterjen merk Make Clean di kalangan laundry Yogyakarta.

Hasil penelitian terhadap PT XYZsebagai produsen dan penjual deterjen merk Make Clean dapat diketahui bahwa terdapat sekitar 300 populasi pengguna deterjen. Dan dalam penelitian ini akan diambil sebanyak 100 sampel yang dianggap dapat mewakili seluruh populasi.

Secara garis besar metode dalam penelitian dapat digambarkan dalam bentuk flowchart sebagai berikut :

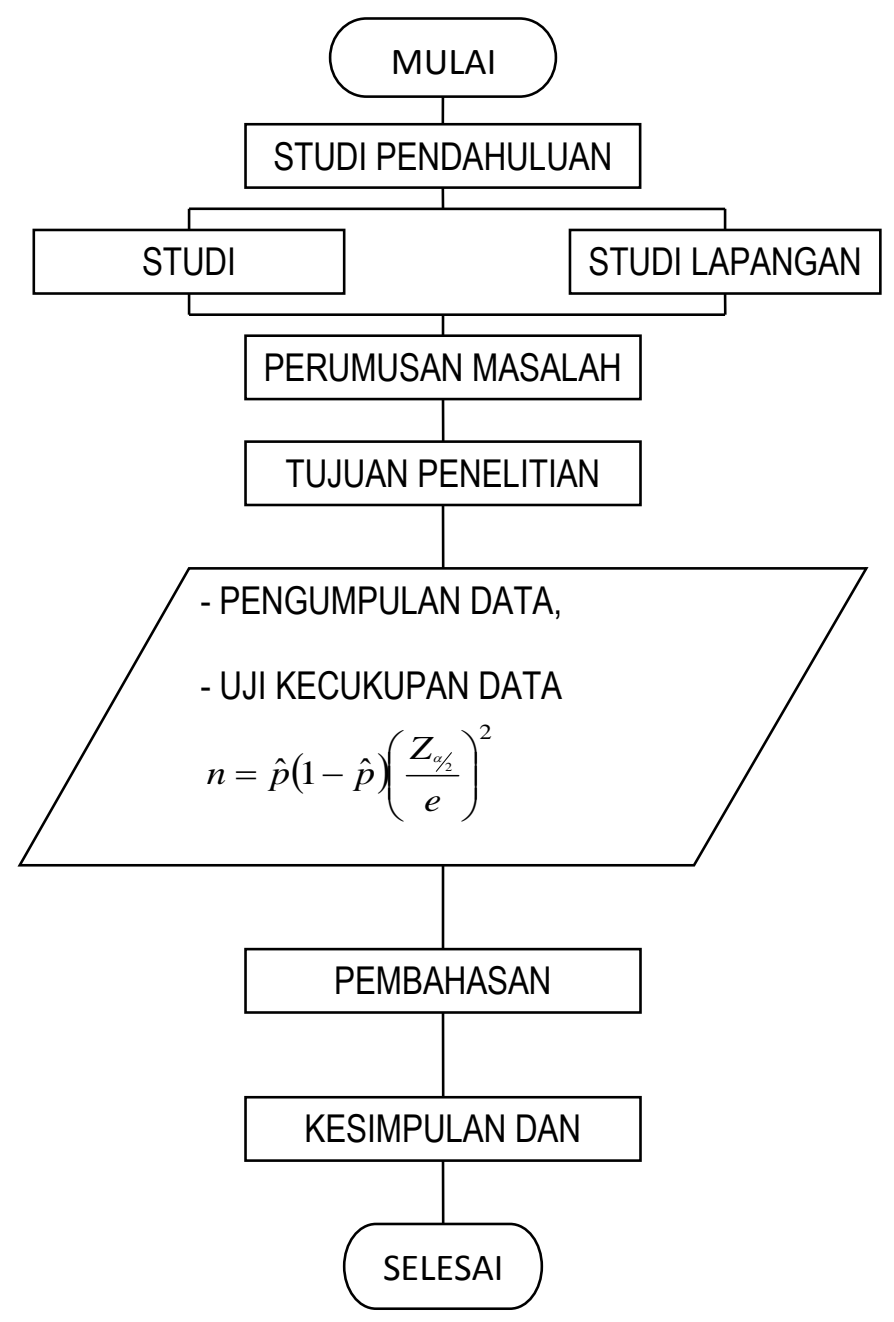

Gambar 1. Flowchart Metodologi Penelitian 


\section{PENGUMPULAN DAN PENGOLAHAN DATA}

\section{A. Pengumpulan Data}

Seperti diuraikan di atas bahwa data diperoleh dengan mengajukan angket (kuisioner) berisi beberapa pertanyaan kepada pengusaha Laundry Yogyakarta. Pertanyaan tersebut berkaitan dengan atribut-atribut deterjen Make Clean Seperti harga, merek, kemasan, promosi dan performansi. Dalam pengumpulan data digunakan alat ukur yang dipakai dalam penyusunan angket (kuisioner) penelitian yaitu dengan Skala Likert yang berisi tingkat jawaban berjumlah 5 (lima) yang merupakan skala jenis ordinal (Erwan, Dyah, 63:2007)

Tingkat jawaban tersebut untuk mengukur opini atau persepsi responden berdasarkan tingkat persetujuan atau ketidaksetujuan. Tingkat jawaban tersebut dikoding/dikelompokkan dengan memberikan angka sebagai berikut :

$4=$ SS (Sangat Setuju),

$3=\mathrm{S}$ (Setuju),

$2=$ TS (Tidak Setuju)

$1=$ STS $($ Sangat Tidak Setuju $)$

$0=$ Netral

Dari 100 responden sebagai sample diperoleh data rata rata sebagai berikut :

Tabel 1.Penilaian Sikap Konsumen

Tabel 2. Hasil Pengumpulan Data rata rata

\begin{tabular}{|c|l}
\hline Frekuensi & \multicolumn{1}{c}{ Keterangan } \\
\hline $6,0-7,5$ & Sangat negatif \\
\hline $7,6-9,0$ & Negatif \\
\hline $9,1-10,5$ & Positif \\
\hline $10,6-12,0$ & Sangat positif \\
\hline
\end{tabular}

Sumber : data interval skor kuisioner

Keterangan: Skor kuisioner terendah 0, tertinggi 12

\begin{tabular}{|l|l|r|r|r|r|r|r|}
\hline No. & Jenis Kelamin & harga & merek & kemasan & promosi & permorfansi & Keseluruhan \\
\hline & & & & & & & \\
\hline 1 & Laki-laki & 8.96 & 8.64 & 8.72 & 7.64 & 9.40 & 44.22 \\
\hline 2 & Wanita & 9.50 & 9.40 & 9.26 & 8.22 & 9.98 & 46.36 \\
\hline
\end{tabular}

\section{B. Uji Kecukupan Data}

Uji kecukupan data dimaksudkan apakah jumlah responden sudah cukup atau belum.

Rumus yang digunakan adalah:

$$
n=\hat{p}(1-\hat{p})\left(\frac{Z_{\alpha / 2}}{e}\right)^{2}
$$

$n=$ jumlah sampel minimal yang harus diambil

$\hat{p}=$ proporsi yang diduga

$e=$ standar error

$\mathrm{Z}=$ nilai tabel distribusi normal untuk tingkat kepercayaan $1-\alpha$.

Jika nilai $\hat{p}$ tidak diketahui maka nilai $\hat{p}(1-\hat{p})$ dapat digantikan dengan nilai maksimumnya yaitu 0,25. Dengan demikian uji kecukupan data untuk kasus ini dapat dihitung sebagai berikut:

$n=0,25\left(\frac{Z_{\alpha / 2}}{e}\right)^{2}$

Tingkat kesalahan yang diharapkan tidak melebihi $10 \%$ maka jumlah responden yang harus dicari adalah:

$n=0,25\left(\frac{1,96}{0,1}\right)^{2}=96,04$ atau dibulatkan menjadi 97 orang responden. 
Dari perhitungan di atas diketahui bahwa jumlah responden yang harus dicari hendaknya lebih dari 97 orang.

\section{Uji Validitas Dan Reliabilitas}

Uji validitas dan reliabilitas digunakan untuk menguji instrumen penelitian dalam hal ini adalah kuisioner .Kuisioner dikatakan valid jika mampu mengukur apa yang seharusnya diukur, dan dikatakan reliabel jika menghasilkan hasil yang konsisten dan stabil dari waktu ke waktu.

Untuk memudahkan pengujian validitas dan reliabilitas kuisioner dalam penelitian ini digunakan bantuan software aplikasi statistik yaitu SPSS 17 .Dari pengolahan data dengan SPSS tersebut akan diperoleh hasil sebagai berikut:

\begin{tabular}{|c|c|c|c|c|c|c|}
\hline \multicolumn{5}{|c|}{$\begin{array}{l}\text { Tabel 3.Hasil uji Validitas Instrumen } \\
\text { Item-Total Statistics }\end{array}$} & \multicolumn{2}{|c|}{$\begin{array}{l}\text { Tabel 4. Hasil uji Reliabilitas Instrumen } \\
\text { Reliability Statistics }\end{array}$} \\
\hline Question & $\begin{array}{l}\text { Scale Mean if } \\
\text { Item Deleted }\end{array}$ & $\begin{array}{c}\text { Scale } \\
\text { Variance if } \\
\text { Item Deleted }\end{array}$ & $\begin{array}{l}\text { Corrected } \\
\text { Item-Total } \\
\text { Correlation } \\
\end{array}$ & $\begin{array}{c}\text { Cronbach's } \\
\text { Alpha if Item } \\
\text { Deleted } \\
\end{array}$ & & \\
\hline $\mathrm{p} 1$ & 41.2667 & 21.444 & .377 & .801 & & \\
\hline p2 & 41.3333 & 21.264 & .464 & .796 & & \\
\hline p3 & 41.4000 & 21.283 & .349 & .803 & Cronbach's & $\mathrm{N}$ of \\
\hline p4 & 41.3000 & 19.183 & .654 & .778 & Alpha & Items \\
\hline p5 & 41.3667 & 19.137 & .715 & .774 & & \\
\hline $\begin{array}{l}\mathrm{p} 6 \\
\mathrm{p} 7\end{array}$ & $\begin{array}{l}41.4667 \\
41.3333\end{array}$ & $\begin{array}{l}20.326 \\
21.540\end{array}$ & $\begin{array}{l}.589 \\
.272\end{array}$ & $\begin{array}{l}.786 \\
.809\end{array}$ & & \\
\hline p8 & 41.2667 & 21.582 & 243 & .813 & & \\
\hline p9 & 41.4333 & 21.357 & .285 & .809 & $8 \cap 0$ & 15 \\
\hline $\mathrm{p} 10$ & 41.5000 & 21.086 & .369 & .802 & , & 15 \\
\hline p11 & 42.2667 & 21.995 & .388 & .801 & & \\
\hline p12 & 42.1333 & 20.671 & .379 & .802 & & \\
\hline p13 & 41.1333 & 21.913 & .392 & .800 & & \\
\hline p14 & 41.3667 & 20.654 & .489 & .793 & & \\
\hline p15 & 41.0333 & 21.344 & .482 & .795 & & \\
\hline
\end{tabular}

\section{Analisis Kualitatif}

Analisis statistik kualitatif ini diperlukan untuk mendeskripsikan data-data yang diperoleh dari responden melalui wawancara dan observasi berdasarkan klasifikasi karakteristik responden. Dalam penelitian ini, klasifikasi karakteristik responden meliputi jenis kelamin, jenis produk yang di pakai, frekuensi mencuci per hari dan kemasan produk yang dipakai. Klasifikasi karakteristik responden di atas dapat dilihat dalam grafik histogram seperti di bawah ini.

Untuk karakteristik jenis kelamin akan diperoleh grafik histogram seperti terlihat di bawah ini. Dari grafik tersebut maka diketahui bahwa sebagian besar responden berjenis kelamin pria yaitu sebanyak 50 orang, dan sisanya 50 orang berjenis kelamin wanita.

Jenis produk Make Clean yang banyak dipakai oleh Laundry Yogyakarta dapat digambarkan dalam grafik di bawah ini. Dari grafik tersebut diketahui bahwa :

1. Make Clean Matic Jusmine $=25$ orang

2. Make Clean Matic Luxia $=55$ orang

3. Make Clean Superbusa $=15$ orang

4. Make Clean Deterjen cair $=5$ orang 


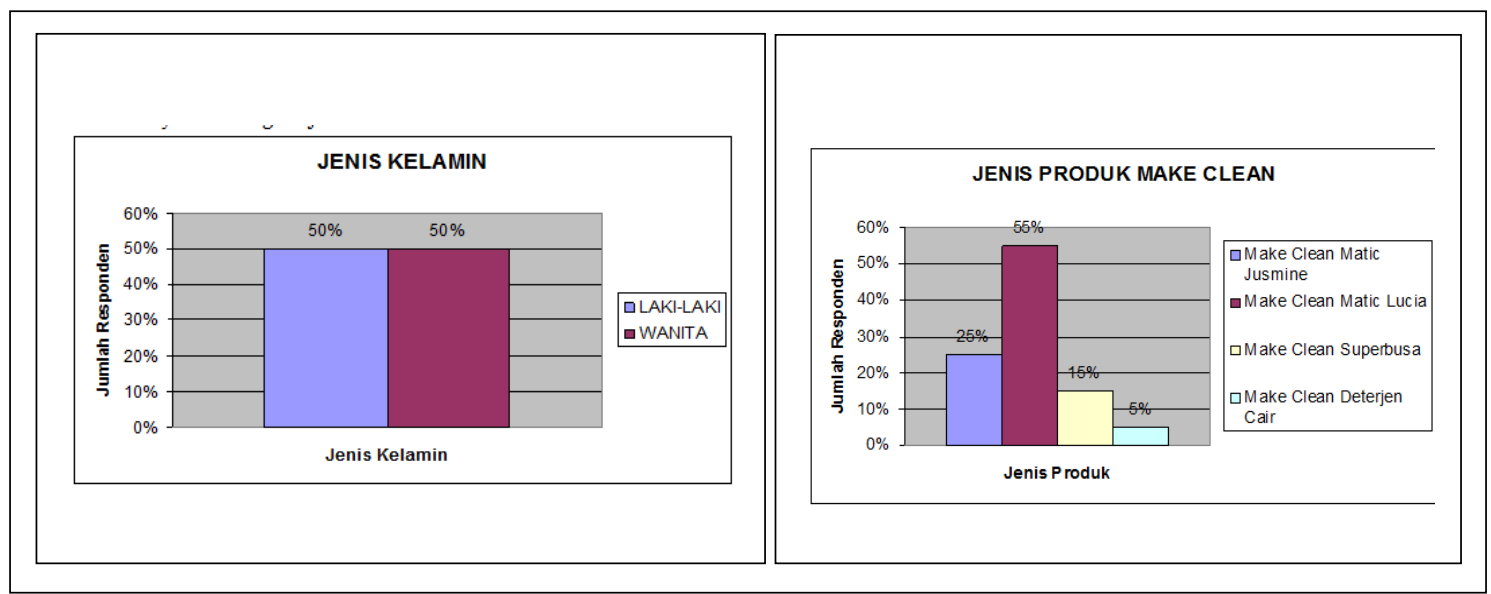

Frekuensi pencucian dalam sehari dari pengusaha dapat digambarkan pada grafik dibawah ini. Dari grafik tersebut dapat diketahui bahwa :
a. $1-4$ kali $=10$ orang
b. $5-8 \mathrm{kali}=36$ orang
c. 9 kali keatas $=54$ orang

Berdasarkan kemasan produk yang dijual di pasaran ternyata responden lebih banyak menggunakan produk dengan kemasan :
a. $1 \mathrm{~kg}$
$=63$ orang
b. $10 \mathrm{~kg}$
$=15$ orang
c. $15 \mathrm{~kg}$
$=15$ orang
d. $20 \mathrm{~kg}$
$=7$ orang

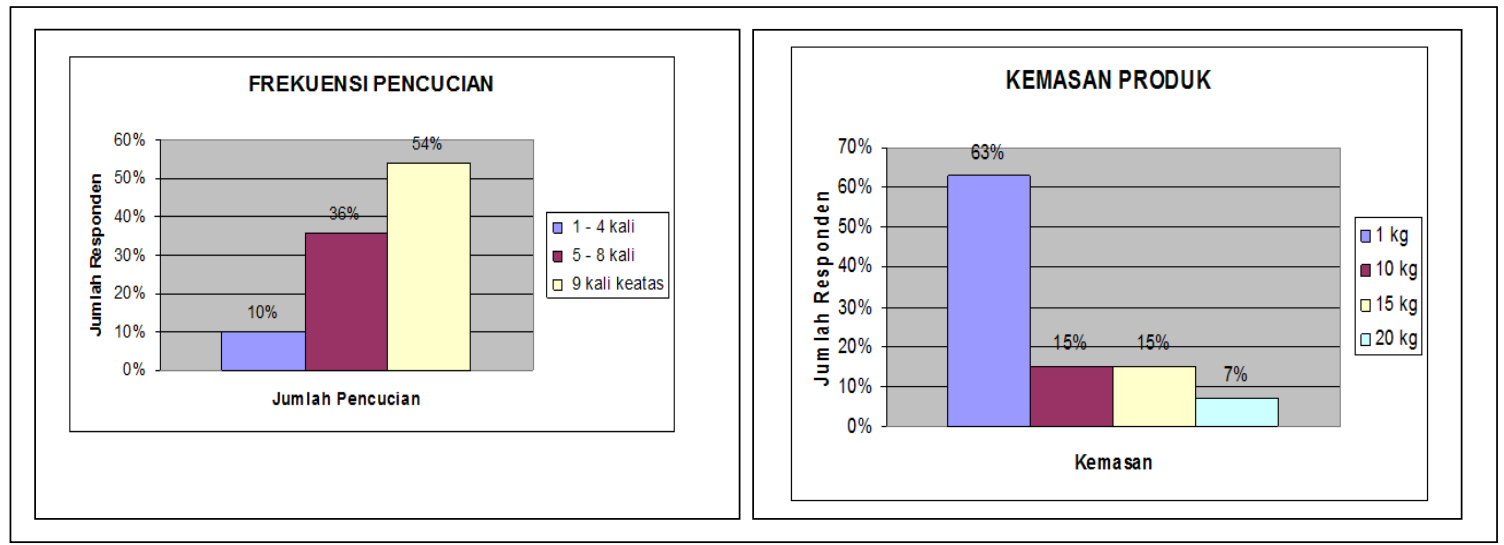

\subsubsection{Analisis Kuantitatif}

Analisa kuantitatif yang dilakukan adalah analisa aritmatik mean dan uji perbedaan rata-rata 2 sampel. Untuk memudahkan 2 pengujian di atas digunakan bantuan software SPSS 17 dengan menggunakan uji yang disebut sebagai Independent-Samples T-test. Untuk masing-masing variabel dapat dilihat di bawah ini.

1. Harga

Dari data yang diperoleh bahwa harga untuk deterjen Make Clean berada pada posisi rata-rata dengan harga jual sebesar Rp. 8.500,- per kg. Sebagai perbandingan, berikut sebagian kompetitor merk Make Clean : 
Tabel 5. Kompetiter dan Harga

\begin{tabular}{|c|c|c|}
\hline Distributor & Merk & Harga \\
\hline Sumber Hidup & Supermatic & Rp. $7.000,00$ \\
\hline PT. Intra Kimia & Scordex & Rp. $8.250,00$ \\
\hline PT. Prometa Abadi & Sanbrite & Rp. $8.250,00$ \\
\hline CV. Dyota Andakarta & Make Clean & Rp. $8.500,00$ \\
\hline Andhika Putra & Fizz & Rp. $\quad 9.000,00$ \\
\hline Cemerlang & Flash & Rp. $9.500,00$ \\
\hline PT. Protekindo & Launtex & Rp. $12.650,00$ \\
\hline
\end{tabular}

\section{Sumber : data PT XYZ}

Berdasarkan hasil pengolahan data kuisioner dengan menggunakan SPSS, maka akan diperoleh hasil yang dapat digunakan untuk melakukan analisis Aritmatik Mean untuk atribut harga sertauntuk uji perbedaan rata-rata 2 sampel untuk atribut harga akan diperoleh hasil seperti terlihat di bawah ini.

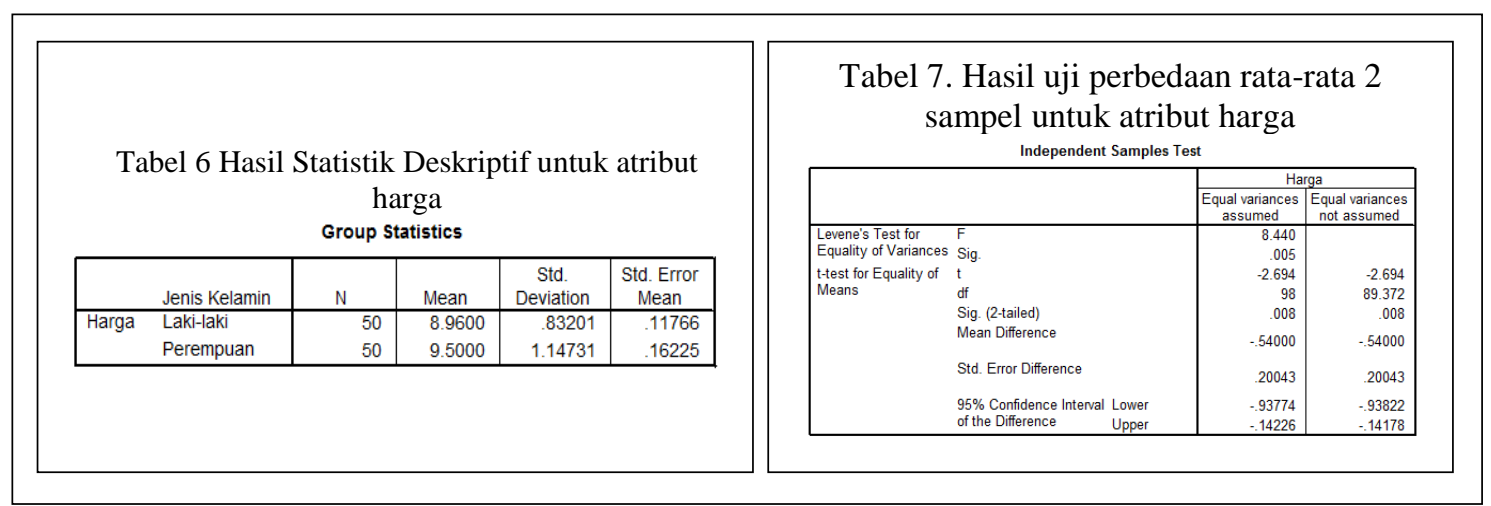

Pada output tersebut terlihat bahwa ada 2 uji yang dapat dilakukan yaitu Uji F untuk menguji kesamaan 2 varian pada atribut harga dan uji $\mathrm{T}$ untuk mengetahui apakah ada perbedaan rata-rata 2 sampel pada atribut harga.

2. Merek

Berdasarkan hasil pengolahan data kuisioner dengan menggunakan SPSS, maka diperoleh hasil yang dapat digunakan untuk melakukan analisis Aritmatik Mean untuk atribut merek,dan untuk uji perbedaan rata-rata 2 sampel akan diperoleh hasil seperti terlihat sebagai berikut.

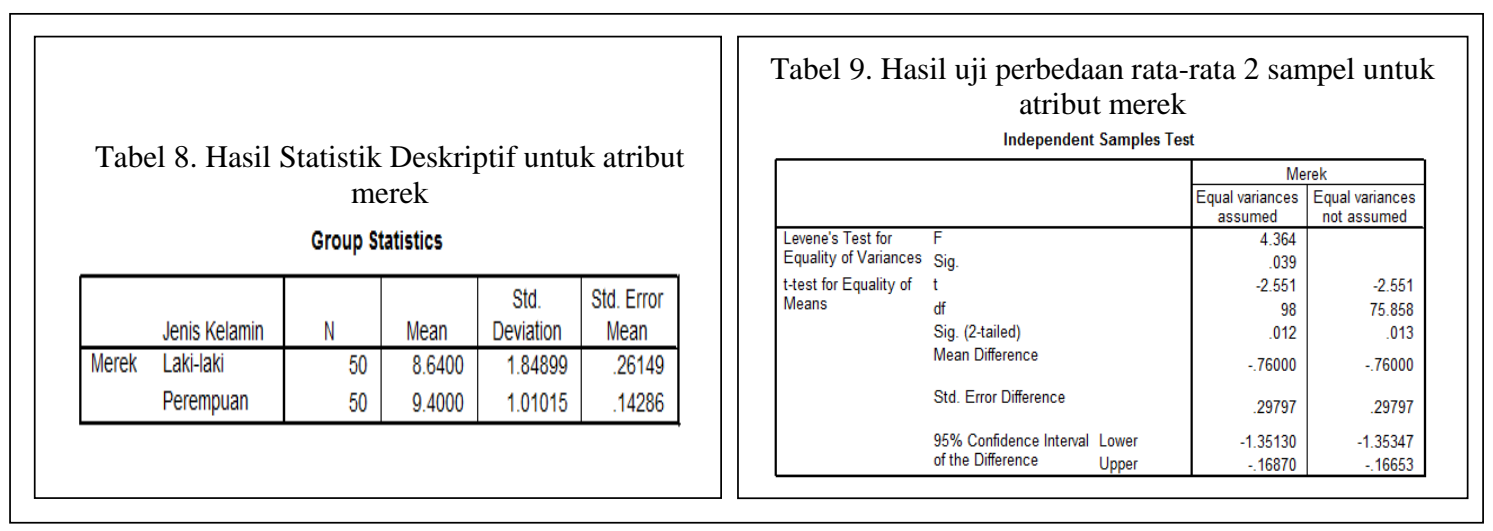

Pada output tersebut terlihat bahwa ada 2 uji yang dapat dilakukan yaitu Uji F untuk menguji kesamaan 2 varian pada atribut merek dan uji T untuk mengetahui apakah ada perbedaan rata-rata 2 sampel pada atribut merek. 


\section{Kemasan}

Kemasan produk deterjen yang dipasarkan ada 4 macam kemasan yaitu $1 \mathrm{~kg}, 10 \mathrm{~kg}$, $15 \mathrm{~kg}$ dan $20 \mathrm{~kg}$. Berdasarkan hasil pengolahan data kuisioner (terlampir) dengan menggunakan SPSS, maka akan diperoleh hasil yang dapat digunakan untuk melakukan analisis Aritmatik Mean untuk atribut kemasan sebagai berikut:

Sedangkan dan untuk uji perbedaan rata-rata 2 sampel akan diperoleh hasil seperti terlihat di bawah ini.

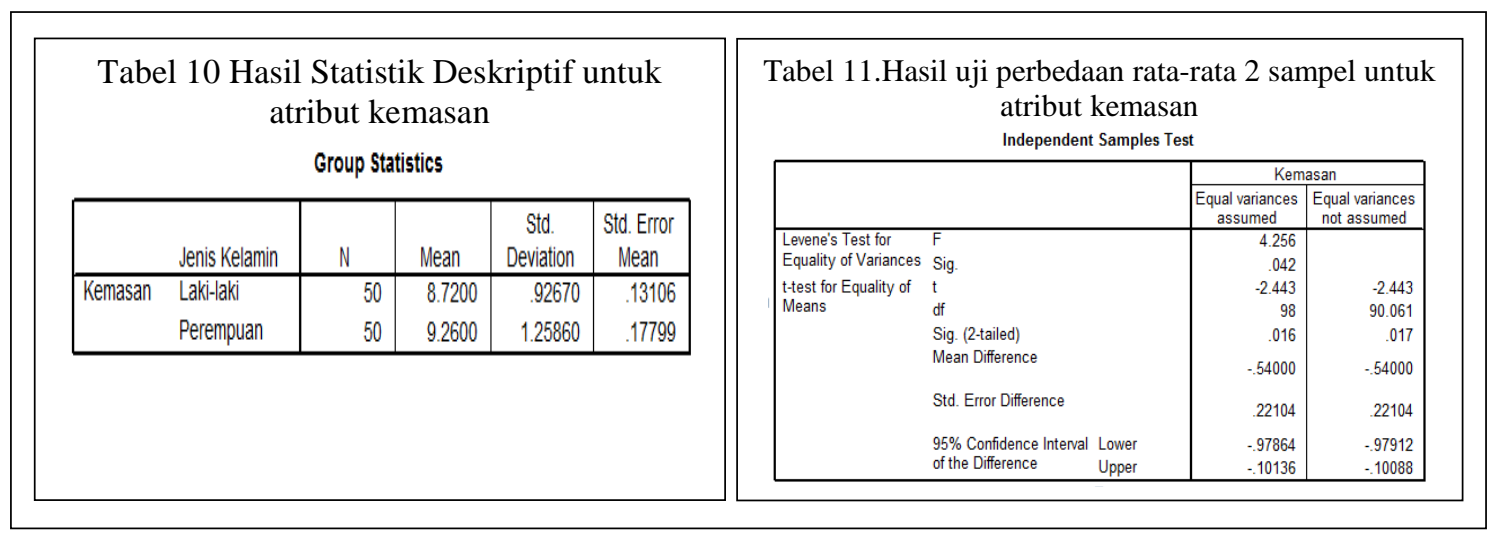

Pada output tersebut terlihat bahwa ada 2 uji yang dapat dilakukan yaitu Uji F untuk menguji kesamaan 2 varian pada atribut kemasan dan uji $\mathrm{T}$ untuk mengetahui apakah ada perbedaan rata-rata 2 sampel pada atribut kemasan.

4. Promosi

Berdasarkan hasil pengolahan data kuisionerdengan menggunakan SPSS, maka akan diperoleh hasil yang dapat digunakan untuk melakukan analisis Aritmatik Mean untuk atribut promosi dan untuk uji perbedaan rata-rata 2 sampel akan diperoleh hasil seperti terlihat di bawah ini.

Tabel 12. Hasil Statistik Deskriptif untuk atribut promosi

Group Statistics

\begin{tabular}{|ll|r|r|r|c|}
\hline & Jenis Kelamin & \multicolumn{1}{|c|}{$\mathrm{N}$} & \multicolumn{1}{c|}{ Mean } & $\begin{array}{c}\text { Std. } \\
\text { Deviation }\end{array}$ & $\begin{array}{c}\text { Std. Error } \\
\text { Mean }\end{array}$ \\
\hline Promosi & Laki-laki & 50 & 7.6400 & 1.25779 & .17788 \\
& Perempuan & 50 & 8.2200 & 1.23371 & .17447 \\
\hline
\end{tabular}

Tabel 13. Hasil uji perbedaan ratrata 2 sampel untuk atribut promosi

Independent Samples Test

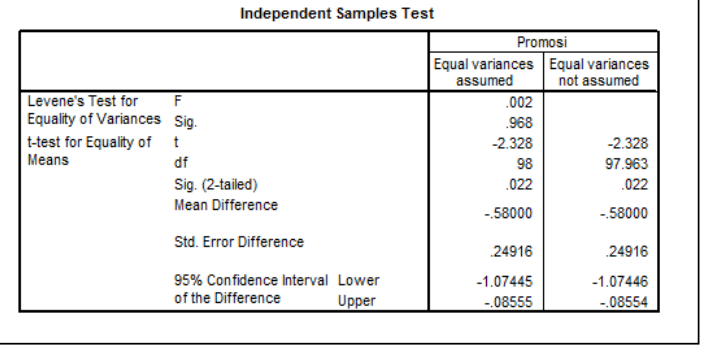

Pada output tersebut terlihat bahwa ada 2 uji yang dapat dilakukan yaitu Uji F untuk menguji kesamaan 2 varian pada atribut promosi dan uji T untuk mengetahui apakah ada perbedaan rata-rata 2 sampel pada atribut promosi.

5. Performansi

Berdasarkan hasil pengolahan data kuisioner (terlampir) dengan menggunakan SPSS, maka akan diperoleh hasil yang dapat digunakan untuk melakukan analisis Aritmatik Mean untuk atribut performansi dan untuk uji perbedaan rata-rata 2 sampel akan diperoleh hasil seperti terlihat di bawah ini. 


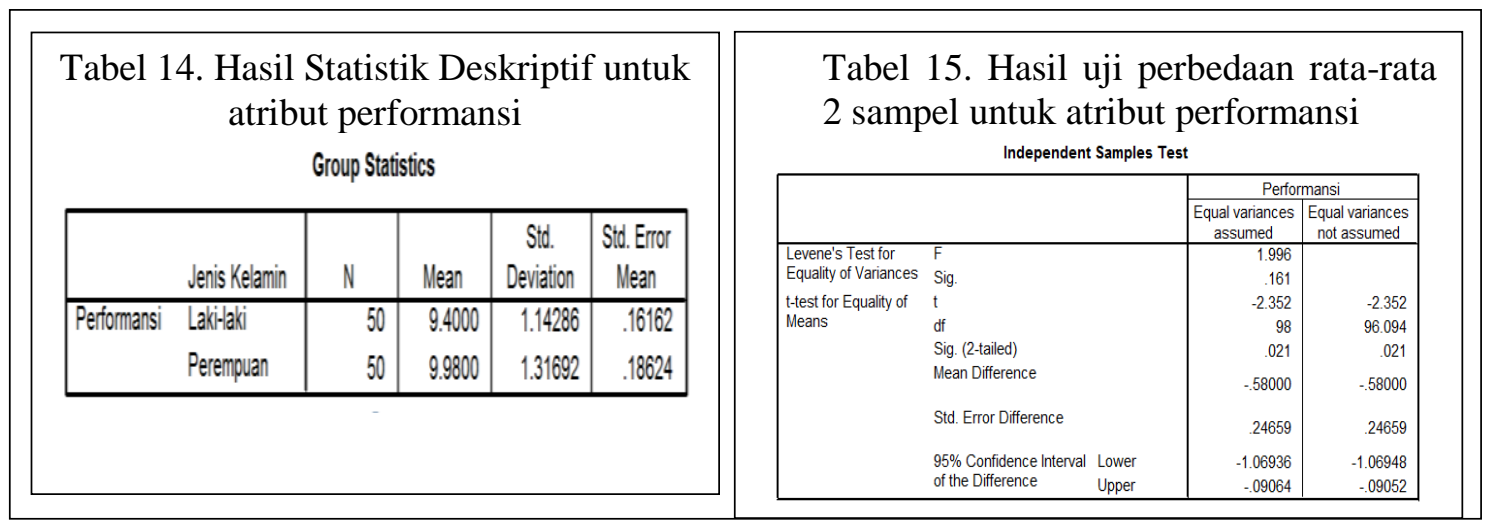

Pada output tersebut terlihat bahwa ada 2 uji yang dapat dilakukan yaitu Uji F untuk menguji kesamaan 2 varian pada atribut performansi dan uji $\mathrm{T}$ untuk mengetahui apakah ada perbedaan rata-rata 2 sampel pada atribut performansi.

6. Rata-rata Keseluruhan Atribut

Berdasarkan hasil pengolahan data kuisioner (terlampir) dengan menggunakan SPSS, maka akan diperoleh hasil yang dapat digunakan untuk melakukan analisis Aritmatik Mean untuk atribut performansi dan untuk uji perbedaan rata-rata 2 sampel akan diperoleh hasil seperti terlihat di bawah ini.

Tabel 16. Hasil Statistik Deskriptif untuk seluruh atribut

Group Statistics

\begin{tabular}{|c|c|c|c|c|c|}
\hline & Jenis Kelamin & N & Mean & $\begin{array}{c}\text { Sto. } \\
\text { Deviation }\end{array}$ & $\begin{array}{l}\text { Sto. Error } \\
\text { Nean }\end{array}$ \\
\hline \multirow[t]{2}{*}{ Keselurhan } & Laki-aki & 50 & 44.2200 & 3.95015 & .55864 \\
\hline & Perempuan & 50 & 46.3600 & 3.45679 & .48880 \\
\hline
\end{tabular}

Tabel 17. Hasil uji perbedaan rata-rata 2 sampel untuk seluruh atribut Independent Samples Test

\begin{tabular}{|c|c|c|c|}
\hline & & \multicolumn{2}{|c|}{ Keseluruhan } \\
\hline & & $\begin{array}{c}\text { Equal variances } \\
\text { assumed }\end{array}$ & $\begin{array}{c}\text { Equal variances } \\
\text { not assumed }\end{array}$ \\
\hline $\begin{array}{l}\text {-evene's Test for } \\
\text { Equality of Variances }\end{array}$ & & $\begin{array}{l}.064 \\
.801\end{array}$ & \\
\hline \multirow{7}{*}{$\begin{array}{l}\text { :-test for Equality of } \\
\text { Means }\end{array}$} & $t$ & -2.883 & -2.883 \\
\hline & df & 98 & 96.306 \\
\hline & Sig. (2-tailed) & .005 & .005 \\
\hline & Mean Difference & -2.14000 & -2.14000 \\
\hline & Std. Error Difference & .74233 & .74233 \\
\hline & 95\% Confidence Interve Lower & -3.61314 & -3.61346 \\
\hline & of the Difference Upper & -66686 & -.66654 \\
\hline
\end{tabular}

Pada output tersebut terlihat bahwa ada 2 uji yang dapat dilakukan yaitu Uji F untuk menguji kesamaan 2 varian pada data rata-rata keseluruhan atribut dan uji $\mathrm{T}$ untuk mengetahui apakah ada perbedaan rata-rata 2 sampel data rata-rata keseluruhan atribut.

\section{ANALISA DAN PEMBAHASAN}

A. Analisa Hasil Uji Kecukupan Data

Dari hasil perhitungan uji kecukupan data diketahui bahwa jumlah responden minimalnya adalah 97 orang. Dalam penelitian ini respondennya ada 100 orang pengusaha laundry. Dengan demikian disimpulkan bahwa data sudah cukup.

\section{B. Analisa Hasil Uji Validitas Dan Reliabilitas}

Sebelum dilakukan analisis data, maka dalam penelitian ini perlu dilakukan pengujian instrumen yaitu pengujian validitas dan reabilitas. Suatu instrumen dikatakan valid jika instrumen ini mampu mengukur apa saja yang ingin diungkapkan. Sedangkan reabilitas menunjukkan sejauh mana suatu instrumen memberikan hasil pengukuran yang konsisten, apabila pengukuran dilakukan berulang-ulang. 
Suatu alat ukur atau instrumen pengumpul data harus memenuhi syarat validitas dan reabilitas, sehingga data yang diperoleh dari pengukuran, jika diolah tidak memberikan hasil yang menyesatkan.

1. Pengujian Validitas

Pengujian validitas bertujuan untuk menguji apakah tiap-tiap butir pertanyaan telah mengungkapkan faktor-faktor lain yang ingin diselidiki sesuai dengan kondisi populasinya.Perhitungan uji validitas ini menggunakan rumus korelasi pearson product moment. Langkah-langkahnya adalah:

a. Menentukan hipotesis

$\mathrm{H}_{0}$ : Skor butir tidak berkorelasi positif dengan skor faktor

$\mathrm{H}_{1}$ : Skor butir berkorelasi positif dengan skor factor

b. Menentukan $r_{\text {tabel }}$

Dengan derajat bebas $(\mathrm{df})=\mathrm{n}-2=100-2=98$; alpha $5 \%$ diperoleh nilai tabel $=0,1292$

c. Menentukan $\mathrm{r}_{\text {hitung }}$

Dari output uji validitas nilai $\mathrm{r}_{\text {hitung }}$ dapat dilihat pada kolom corrected item total correlation.

d. Dasar Pengambilan Keputusan

Jika $r_{\text {hitung }}$ positif $>r_{\text {tabel }}$, maka butir tersebut valid

Jika $r_{\text {hitung }}$ positif $<r_{\text {tabel }}$, maka butir tersebut tidak valid.

Dari hasil tersebut diketahui bahwa 15 butir pertanyaan (lihat lampiran kuisioner) semuanya valid karena $r_{\text {hitung }}$ positif dan lebih besar dari $r_{\text {tabel. }}$.

Tabel 18.Rangkuman Hasil Uji Validitas dan Reliabilitas

\begin{tabular}{c|c|c|c|c}
\hline Pertanyaan & $\mathbf{r}_{\text {hitung }}$ & $\mathbf{r}_{\text {tabel }}$ & Keterangan & Kesimpulan \\
Butir 1 & 0,377 & 0,1292 & $\mathrm{H}_{0}$ diterima & Valid \\
Butir 2 & 0,464 & 0,1292 & $\mathrm{H}_{0}$ diterima & Valid \\
Butir 3 & 0,349 & 0,1292 & $\mathrm{H}_{0}$ diterima & Valid \\
Butir 4 & 0,654 & 0,1292 & $\mathrm{H}_{0}$ diterima & Valid \\
Butir 5 & 0,715 & 0,1292 & $\mathrm{H}_{0}$ diterima & Valid \\
Butir 6 & 0,589 & 0,1292 & $\mathrm{H}_{0}$ diterima & Valid \\
Butir 7 & 0,272 & 0,1292 & $\mathrm{H}_{0}$ diterima & Valid \\
Butir 8 & 0,243 & 0,1292 & $\mathrm{H}_{0}$ diterima & Valid \\
Butir 9 & 0,285 & 0,1292 & $\mathrm{H}_{0}$ diterima & Valid \\
Butir 10 & 0,369 & 0,1292 & $\mathrm{H}_{0}$ diterima & Valid \\
Butir 11 & 0,388 & 0,1292 & $\mathrm{H}_{0}$ diterima & Valid \\
Butir 12 & 0,379 & 0,1292 & $\mathrm{H}_{0}$ diterima & Valid \\
Butir 13 & 0,392 & 0,1292 & $\mathrm{H}_{0}$ diterima & Valid \\
Butir 14 & 0,489 & 0,1292 & $\mathrm{H}_{0}$ diterima & Valid \\
Butir 15 & 0,482 & 0,1292 & $\mathrm{H}_{0}$ diterima & Valid
\end{tabular}

2. Pengujian Reliabilitas

Pengujian reliabilitas ini hanya dilakukan terhadap butir-butir yang valid, yang diperoleh melalui uji validitas.Dan hasil uji validitas, terlihat bahwa kesemua variabel adalah valid, karena semuanya mempunyai nilai $r_{x y}>r_{\text {tabel }}$ dan semuanya adalah positif. Langkah-langkah uji reliabilitas adalah:

a. Menentukan Hipotesis

$\mathrm{H}_{0}$ : Skor butir tidak berkorelasi (+) dengan skor faktor

$\mathrm{H}_{1}$ : Skor butir berkorelasi (+) dengan skor faktor

b. Menentukan $r_{\text {tabel }}$

Dengan derajat bebas $(\mathrm{df})=\mathrm{n}-2=100-2=98$; alpha $5 \%$ diperoleh nilai tabel $=0,1292$ 
c. Menentukan $\mathrm{r}_{\text {hitung }}$

Dari output uji reliabilitas diperoleh nilai alpha cronbach sebesar 0,859.

d. Dasar Pengambilan Keputusan

Jika $r_{\text {hitung }}$ positif $>r_{\text {tabel}}$, maka butir tersebut reliabel

Jika $\mathrm{r}_{\text {hitung }}$ positif $<\mathrm{r}_{\text {tabel}}$, maka butir tersebut tidak reliabel.

Pada analisis diatas dapat dilihat bahwa $r_{\text {hitung }}$ positif dan $>r_{\text {tabel }}$, maka kuisioner yang diajukan kepada respoden tersebut reliabel.

\section{Analisis Kualitatif}

Analisis ini didasarkan pada hasil jawaban yang diperoleh dari para responden dengan membuat daftar tabel deskriptif.

1. Karakteristik pengusaha laundry berdasarkan jenis kelamindapat diketahui bahwa responden dalam penelitian ini adalah pria sebanyak 50 orang atau sebesar $50 \%$ dan wanita sebanyak 50 orang atau $50 \%$.

2. Pertanyaan tentang sikap konsumen

a. Produk deterjen merek Make Clean yang paling banyak dipakai dapat diketahui bahwa responden dalam penelitian ini untuk jenis produk yang paling banyak dipakai adalah Make Clean Luxia sebesar 55\%.

b. Berapa banyak menggunakanproduk deterjen merek Make Clean dalam seharidapat diketahui bahwa responden dalam penelitian ini untuk jumlah konsumsi per hari 1-4 kali sebanyak 10 orang atau 10\%, 5-8 kali sebanyak 36 orang atau $36 \%$,dan lebih dari 9 kali sebanyak 54 orang atau $54 \%$.

c. Jenis kemasan kilogram dalam penggunaan deterjen merek Make Clean dapat diketahui bahwa responden dalam melakukan pembelian produk deterjen merek Make Clean kemasan $1 \mathrm{~kg}$ gram sebanyak 63 orang atau sebesar 63\%, kemasan $10 \mathrm{~kg}$ sebanyak 15 orang atau sebesar $15 \%$, kemasan $15 \mathrm{~kg}$ sebanyak 15 orang atau sebesar $15 \%$, kemasan 20 gram sebanyak 7 orang atau sebesar $7 \%$.

\section{Analisis Kuantitatif}

Analisis kuantitatif adalah metode analisis data yang dilaksanakan dengan menggunakan alat-alat statistik untuk menguji hipotesis yang telah dirumuskan dan dapat mengambil kesimpulan/keputusan yang berkenaan dengan data dari kuisioner yang didapat.

\section{E. Analisis Aritmatik Mean (Rata-Rata Hitung)}

Analisis Aritmatik Mean (Rata-Rata Hitung) bertujuan untuk mengetahui sikap pengusaha laundry terhadap atribut produk deterjen merek Make Clean, yaitu dengan menjumlahkan seluruh nilai dan membaginya dengan jumlah individu masing-masing skor pada skala likert.Sedangkan responden dalam penelitian ini di bedakan berdasarkan jenis kelamin. Untuk membandingkan hasil nilai rata-rata hitung sebagai berikut ini:

1. Sikap pengusaha laundry pria

a. Nilai rata-rata hitung pengusaha laundry pria terhadap atribut harga pada deterjen merek Make Clean.

Dari tabel 6, dapat diketahui bahwa persepsi pengusaha laundry pria terhadap atribut harga deterjen merek Make Clean mempunyai nilai rata-rata hitung 8,96. Karena nilai rata-rata hitung 8,96 berada pada interval $7,6-9,0$ maka persepsi pengusaha laundry pria mempunyai penilaian negatif terhadap atribut harga.

b. Nilai rata-rata hitung pengusaha laundry pria terhadap atribut merek deterjen merek Make Clean.

Dari tabel 8, dapat diketahui bahwa persepsi pengusaha laundry pria terhadap atribut merek deterjen merek Make Clean mempunyai nilai rata-rata hitung 
8,64. Karena nilai rata-rata hitung 8,64 berada pada interval 7,6-9,0 maka persepsi pengusaha laundry pria mempunyai penilaian negatif terhadap atribut merk.

c. Nilai rata-rata hitung pengusaha laundry pria terhadap atribut kemasan deterjen merek Make Clean.

Dari tabel 10, dapat diketahui bahwa persepsi pengusaha laundry pria terhadap atribut kemasan deterjen merek Make Clean mempunyai nilai rata-rata hitung 8,72 . Karena nilai rata-rata hitung 8,72 berada pada interval $7,6-9,0$ maka persepsi pengusaha laundry pria mempunyai penilaian negatif terhadap atribut kemasan.

d. Nilai rata-rata hitung pengusaha laundry pria terhadap atribut promosi deterjen merek Make Clean.

Dari tabel 12, dapat diketahui bahwa persepsi pengusaha laundry pria terhadap atribut promosi deterjen merek Make Clean mempunyai nilai rata-rata hitung 7,64. Karena nilai rata-rata hitung 7,64 berada pada interval 7,6-9,0 maka persepsi pengusaha laundry pria mempunyai penilaian negatif terhadap atribut promosi.

e. Nilai rata-rata hitung pengusaha laundry pria terhadap atribut performansi deterjen merek Make Clean.

Dari tabel 14, dapat diketahui bahwa persepsi pengusaha laundry pria terhadap atribut performansi deterjen merek Make Clean mempunyai nilai rata-rata hitung 9,40. Karena nilai rata-rata hitung 9,40 berada pada interval 9,1-10,50 maka persepsi pengusaha laundry pria mempunyai penilaian positif terhadap atribut performansi.

Dari tabel di atas, dapat diambil suatu keputusan bahwa rata-rata hitung sikap pengusaha laundry pria terhadap atribut produk deterjen merek Make Clean memiliki total nilai rata-rata hitung sebesar 44.22 dibagi 5 atribut adalah $\mathbf{8 , 8 4}$. Karena total nilai rata-rata hitung $\mathbf{8 , 8 4}$ berada pada interval 7,6 - 9,00. dengan demikian dapat diklasifikasikan sikap pengusaha laundry pria negatif terhadap pengguna deterjen merek Make Clean.

2. Sikap pengusaha laundry wanita

a. Nilai rata-rata hitung pengusaha laundry wanita terhadap atribut harga pada deterjen merek Make Clean.

Dari tabel 6 dapat diketahui bahwa persepsi pengusaha laundry wanita terhadap atribut harga deterjen merek Make Clean mempunyai nilai rata-rata hitung 9,50. Karena nilai rata-rata hitung 9,50 berada pada interval 9,1-10,5 maka persepsi pengusaha laundry wanita mempunyai penilaian positif terhadap atribut harga.

b. Nilai rata-rata hitung pengusaha laundry wanita terhadap atribut merek pada deterjen merek Make Clean.

Dari tabel 8, dapat diketahui bahwa persepsi pengusaha laundry wanita terhadap atribut merek deterjen merek Make Clean mempunyai nilai rata-rata hitung 9,40. Karena nilai rata-rata hitung 9,40 berada pada interval 9,1-10,5 maka persepsi pengusaha laundry wanita mempunyai penilaian positif terhadap atribut merk.

c. Nilai rata-rata hitung pengusaha laundry wanita terhadap atribut kemasan pada deterjen merek Make Clean.

Dari tabel 10, dapat diketahui bahwa persepsi pengusaha laundry wanita terhadap atribut kemasan deterjen merek Make Clean mempunyai nilai rata-rata hitung 9,26. Karena nilai rata-rata hitung 9,26 berada pada interval 9,1-10,5 maka persepsi pengusaha laundry wanita mempunyai penilaian positif terhadap atribut kemasan. 
d. Nilai rata-rata hitung pengusaha laundry wanita terhadap atribut promosi pada deterjen merek Make Clean.

Dari tabel 12, dapat diketahui bahwa persepsi pengusaha laundry wanita terhadap atribut promosi deterjen merek Make Clean mempunyai nilai rata-rata hitung 8,22. Karena nilai rata-rata hitung 8,22 berada pada interval 7,6- 9,0 maka persepsi pengusaha laundry wanita mempunyai penilaian negatif terhadap atribut promosi.

e. Nilai rata-rata hitung pengusaha laundry wanita terhadap atribut performansi pada deterjen merek Make Clean.

Dari tabel 14, dapat diketahui bahwa persepsi pengusaha laundry wanita terhadap atribut performansi deterjen merek Make Clean mempunyai nilai ratarata hitung 9,98. Karena nilai rata-rata hitung 9,98 berada pada interval 9,1-10,5 maka persepsi pengusaha laundry wanita mempunyai penilaian positif terhadap atribut performansi.

Dari tabel di atas, dapat diambil suatu keputusan bahwa rata-rata hitung sikap pengusaha laundry wanita terhadap atribut produk deterjen merek Make Clean memiliki total nilai rata-rata hitung sebesar 46,36 dibagi 5 atribut adalah 9,27. Karena total nilai rata-rata hitung 9,27 berapa pada interval 9,1-10,5 dengan demikian dapat diklasifikasikan sikap pengusaha laundry wanita positif terhadap pengguna deterjen merek Make Clean.

Dari hasil di atas, dapat disimpulkan bahwa sikap pengusaha laundry pria mempunyai penilaian negatif dan wanita mempunyai penilaian positif terhadap atribut-atribut deterjen merek Make Clean, sehingga terjadi perbedaan.

\section{F. Analisis Uji F}

Uji F dimaksudkan untuk mengetahui apakah 2 buah populasi mempunyai varian yang sama. Langkah-langkahnya adalah sebagai berikut:

1. Menentukan Hipotesis

Hipotesis yang digunakan adalah:

$\mathrm{H}_{0}$ : Kedua populasi mempunyai varian yang sama

$\mathrm{H}_{1}$ : Kedua populasi mempunyai varian yang tidak sama

2. Menentukan Daerah kritis

$\mathrm{H}_{0}$ ditolak jika probabilitas kurang dari 0,05 dan $\mathrm{H}_{0}$ diterima jika probabilitas lebih dari 0,05

3. Pengambilan Keputusan

Dari output SPSS diperoleh probabilitas (dapat dilihat dalam baris Sig). Untuk masing-masing variabel dapat dilihat di bawah ini.

Tabel 19.Rekap Signifikansi Uji F

\begin{tabular}{c|c|c|c|c}
\hline No & Atribut & Sig. & Keputusan & Kesimpulan \\
1 & Harga & 0,005 & $\mathrm{H}_{0}$ ditolak & Varian tidak sama \\
2 & Merek & 0,039 & $\mathrm{H}_{0}$ diterima & Varian sama \\
3 & Kemasan & 0,042 & $\mathrm{H}_{0}$ diterima & Varian sama \\
4 & Promosi & 0,968 & $\mathrm{H}_{0}$ diterima & Varian sama \\
5 & Performansi & 0,161 & $\mathrm{H}_{0}$ diterima & Varian sama \\
6 & Keseluruhan & 0,801 & $\mathrm{H}_{0}$ diterima & Varian sama \\
\hline
\end{tabular}

Dengan demikian atribut yang memiliki varian yang tidak sama adalah harga. 


\section{G. Analisis uji Beda 2 Mean}

Analisis uji beda 2 mean digunakan untuk mengukur harga perbedaan 2 mean $\left(\mu_{1}=\right.$ $\mu_{2}$ ). Asumsi yang digunakan untuk uji ini adalah varian kedua populasi sama. Dari uji F di atas diketahui bahwa atribut promosi dan performansi yang memiliki varian tidak sama. Langkah-langkah uji perbedaan 2 mean adalah sebagai berikut:

1. Menentukan Hipotesis
$\mathrm{H}_{0}: \mu_{1}=\mu_{2}$
Tidak ada perbedaan sikap antara pengusaha laundry pria dan wanita terhadap atribut deterjen merek Make Clean.
$\mathrm{H}_{1}: \mu_{1} \neq \mu_{2}$ Ada perbedaan sikap antara pengusaha laundry pria dan wanita terhadap atribut deterjen merek Make Clean

2. Menentukan $\mathrm{Z}_{\text {tabel }}$

Dari tabel distribusi normal standar diperoleh nilai $Z_{\frac{\alpha}{2}}=1,96$ dan $Z_{\left(1-\frac{\alpha}{2}\right)}=-1,96$.

3. Menentukan $Z_{\text {hitung }}$

Karena dalam SPSS tidak menyediakan tools untuk melakukan uji Z maka nilai $Z_{\text {hitung }}$ dapat digantikan dengan nilai $t_{\text {hitung. }}$.

4. Dasar Pengambilan Keputusan

Jika $Z_{\text {hitung }}>1,96$ atau $Z_{\text {hitung }}<-1,96$ maka $\mathrm{H}_{0}$ ditolak selain itu $\mathrm{H}_{0}$ diterima.

Dari pengolahan data dengan SPSS maka diperoleh hasil sebagai berikut:

Tabel 20. Rekapitulasi Uji Analisis Sikap Konsumen Pria Dan Wanita

Terhadap Atribut Produk deterjen merek Make Clean

\begin{tabular}{l|c|c|l|c}
\multicolumn{1}{c|}{ Atribut } & $\mathbf{Z}_{\text {tabel }}$ & $\mathbf{Z}_{\text {hitung }}$ & \multicolumn{1}{c|}{ Keputusan } & Kesimpulan \\
Harga & $+1,96$ & $-2,694$ & $\mathrm{H}_{0}$ ditolak & $\mu_{1} \neq \mu_{2}$ \\
Merek & $+1,96$ & $-2,561$ & $\mathrm{H}_{0}$ ditolak & $\mu_{1} \neq \mu_{2}$ \\
Kemasan & $+1,96$ & $-2,443$ & $\mathrm{H}_{0}$ ditolak & $\mu_{1} \neq \mu_{2}$ \\
Promosi & $+1,96$ & $-2,328$ & $\mathrm{H}_{0}$ ditolak & $\mu_{1} \neq \mu_{2}$ \\
Performansi & $+1,96$ & $-2,352$ & $\mathrm{H}_{0}$ ditolak & $\mu_{1} \neq \mu_{2}$ \\
Keseluruhan & $+1,96$ & $-2,883$ & $\mathrm{H}_{0}$ ditolak & $\mu_{1} \neq \mu_{2}$
\end{tabular}

Dari tabel rekapitulasi di atas, uji analisis sikap pengusaha laundry pria dan wanita terhadap produk deterjen di kalangan Laundry Yogyakarta per atribut, menunjukan bahwa semua atribut menolak hipotesis nol $\left(\mathrm{H}_{0}\right)$,. Ini berarti menunjukkan adanya perbedaan sikap yang signifikan antara pengusaha laundry pria dan wanita terhadap pengguna deterjen merk Make Clean.

Dari hasil uji analisis sikap pengusaha laundry pria dan wanita secara keseluruhan nilai $Z_{\text {hitung }}$ sebesar $-2,883$. Nilai ini berada diluar daerah penerimaan $\mathrm{H}_{0}$. Ini berarti bahwa analisis sikap pengusaha laundry pria dan wanita terhadap deterjen merek Make Clean di kalangan Laundry Yogyakarta terdapat perbedaan yang signifikan.

\section{KESIMPULAN DAN SARAN}

Berdasarkan hasil penelitian tentang analisis sikap pengusaha laundry pria dan wanita terhadap produk deterjen merek Make Clean di kalangan Laundry dapat ditarik suatu kesimpulan sebagai berikut:

1. Sikap pengusaha laundry pria mempunyai sikap negatif terhadap atribut-atribut produk yaitu harga, merk, kemasan, promosi dan performansi. Sedangkan sikap pengusaha laundry wanita mempunyai sikap positif terhadap atribut-atribut produk yaitu harga, merk, kemasan, promosi dan performansi. 
2. Dari pengujian diperoleh jawaban bahwa terjadi perbedaan sikap antara pengusaha laundry pria dan pengusaha wanita terhadap deterjen merk Make Clean di kalangan laundry Yogyakarta berdasar atribut-atribut produk yaitu harga, merk, kemasan, promosi dan performansi.

3. Dari kelima atribut ternyata yang paling mempengaruhi pengusaha laundry dalam melakukan pembelian produk deterjen merk Make Clean adalah atribut performansi karena mempunyai nilai rata-rata tertinggi dibanding dengan atribut yang lain.

\section{SARAN}

1. Perusahaan deterjen merek Make Clean sebaiknya perlu melakukan strategi yang lebih baik lagi dalam melakukan promosi, sehingga semua lapisan konsumen pengguna deterjen dapat benar-benar mengenal dan merasakan produk deterjen merek Make Clean, seperti kegiatan-kegiatan advertising, personal selling, promosi penjualan, public relations.

2. Performansipada produk deterjen merek Make Clean hendaknya selalu dipertahankan sehingga konsumen yang ada tidak beralih ke produk atau merek lain.

\section{DAFTAR PUSTAKA}

[1] Afifudin G, Saebani Beni Ahmad (2009), Metodologi Penelitian Kualitatif, CV. Pustaka Setia.

[2] Basu Swasta, Handoko T. Hani (1984), Manajemen Pemasaran Analisis Perilaku Konsumen, PT. BPFE UGM.

[3] CV. Dyota Andakara (2009), Daftar Pelanggan Laundry

[4] Erwan A.P., Dyah R.S. (2007), Metode Penelitian Kuantitatif, Untuk Aministrasi Publik Dan Masalah-masalah Sosial, Gava Media, Yogyakarta.

[5] Philip Kottler \& Kevin Keller (2007), Manajemen Pemasaran, PT. Indeks.

[6] Saleh Samsubar (1998), Statistik Deskriptip, UPP AMP YKPN

[7] Simamora Bilson (2005), Analisis Multivariat Pemasaran, Gramedia Pustaka Utama.

[8] Suharso Puguh (2009), Metode Penelitian Kuantitatif untuk Bisnis, PT. Indeks.

[9] Supranto (2009), The Power of Statistik, Pengumpulan dan Pengolahan Data, Penerbit Salemba Empat.

[10] Sutojo Siswanto (2009), Manajemen Pemasaran (Perilaku Konsumen \& Pengambilan Keputusan), PT. Damar Mulia Pustaka.

[11] Umar Husein (2002), Riset Pemasaran dan Perilaku Konsumen, Gramedia Pustaka Utama.

[12] Wisno Komputer (2010), Mengolah Data Statistik Hasil Penelitian dengan SPSS 17, Penerbit Andi, Yogyakarta 